\title{
Basic Principles of National and International Standards Convergence in Teaching Languages for Non-Linguistic Students
}

\author{
Marina Vorontsova ${ }^{1} \mathrm{PhD}$; Olga Vishnyakova ${ }^{2} \mathrm{PhD}$ \\ Lomonosov Moscow State University; Russia \\ mworonzowa@gmail.com ${ }^{1}$; ol-vish@ mail.ru $^{2}$
}

\begin{abstract}
The topicality of the research is the use of modern theories of speech generation, developed in neuro-linguistics, including the disquisitions of the Moscow Psychological School, for the development of new foreign language teaching programs. The aim of the present research is to identify the basic principles for the convergence of national and international foreign language teaching standards - the opportunities and necessary conditions. Change in the approaches to the learning process as well as purposes of instruction, and methods of teaching and control, are considered to be the basic principles of convergence. The pivotal methodology of this study deals with the comparison of learning outcomes with the necessary competencies for graduates of non-linguistic specialties. The results of the research demonstrate the importance of combining communicative and cognitive approaches, as well as implementation of flipped learning, mobile learning, adaptive learning. The analysis of the theory of speech production in the Moscow psychological school enables the researchers to make conclusions about the necessity of combining communicative and cognitive approaches in the course of foreign language teaching. The use of these approaches makes it possible to activate the both hemispheres of the brain. Adaptation of the methods to the ultimate goal of learning and using the speech production principles will result in bridging the gap between the Western and Russian standards.
\end{abstract}

Keywords: university education, standards, competencies, convergence, speech production, approach.

\section{Introduction}

The existence of the Russian and Western standards (Common European Framework..., 2017) dealing with the study of foreign languages, is the heritage of the historical past and the conservatism of Russian tradition in teaching foreign languages, which is based solely on the grammar-translation method. In Russia the foreign languages study programs for quite a long period of time have been based on the knowledge of language structure and the rules of formation of linguistic paradigms. The purpose of learning a foreign language for non-linguistic students was to make them able to perform translation (with the help of a dictionary) from a foreign language into Russian and to make them understand grammatical structures in terms of their correspondence with those of the Russian language.

The practical application of the language did not play a significant role in the educational process. This was determined by the ideological factors to a great extent. Nowadays such factors as the Bologna process (Bologna Declaration, 1999) concepts elaboration, the universities curricular elaboration for the Russian and foreign diplomas, the availability of education programs with a compulsory year or semester at a foreign university, the possibility to get a university degree in any another country, the university mobility implementation make the problem of convergence of national and international standards extremely important.

First and foremost, this concerns foreign language learning programs, since this subject is present in all the curricula of all the universities in question and it can be regarded as the basis of academic mobility in general. It should be noted within these lines that the convergence of standards does not so much imply the general education contents as there always be at least slight differences based on certain traditions and mentality, goals and approaches to knowledge and concepts, described both in linguodidactic disquisitions as well as practical manuals.

At the same time, the common methods and approaches in teaching, monitoring and evaluating the quality of the results should be taken into consideration in terms of convergence phenomena. Thus, the aim and purpose of the present work is to identify the basic principles for the Russian and Western educational standards convergence, taking the Russian tradition scientific achievements into consideration. The analysis of works of the researchers, the Moscow psychological school representatives, in the field of mechanisms of speech generation studies, conducted in the 2 nd half of 
the 20th century, determines the possibility to apply their issues to the Russian methods of teaching that can serve as the basic principle for the Russian and Western standards convergence.

We have to state with a share of regret that in Russia, the principles of the Moscow psychological school have not become part of the recent tradition of teaching in its due course, as it was mostly based on the old conservative representations. Thus, the aim of this report is to make an attempt to prove that the new competency-based standards in Russia (Obrazovatelnyj standart vishevo..., 2015) and the Western standards (Common European Framework..., 2017) are quite similar and focused on the practical application of a foreign language, and to demonstrate that the principles of the Moscow psychological school should be used as the basis of the domestic educational traditions to achieve the goal of convergence with the Western standards. The comparison of key thesis of neuro-linguistics in the works of L. Vygotsky (1987), A.R. Luria (1980), and T.V. Axutina (2014) with the principles of the communicative approach and the modern concepts of teaching developed in the Western tradition (mobile learning, adaptive learning, and flipped learning) is a new approach, which should be used in creating new programs in foreign languages learning in Russia.

\section{Methodology}

The methodology of this research consists in comparing the traditional for the Russian educational system university methodology with that based on the modern international standards and competencies for non-linguistic students, where the use of a foreign language is required. To achieve reliable and valid results in terms of practical application of the knowledge of L2 and L3, we have conducted a survey of graduates from the Institute of Asian and African Studies at M.V. Lomonosov Moscow State University concerning their use of a foreign language in the present course of their practical activities. The main conclusion we have come to is that the graduates in question demonstrate fluency in a foreign language, due to the use of communicative teaching and learning method (11 graduates). At the same time 9 graduates of the years earlier (the period before 2000) face various difficulties in a foreign language skills application, as it is characterized with insufficient learning as far as the number of classes and the use of communication approach are concerned. On the whole, the choice of respondents was diverse: all of them are the university graduates, of different age and sex, the spheres of their activities are business, administration, including international organizations, education (getting Master's degree) in Russia and abroad (European countries). Thus, the basic conclusion of the survey analysis is that the previous standard was not focused on the practical application of linguistic knowledge and that it does not provide the basis for the further language development.

The second survey has been conducted with the other 20 respondents, whose occupation is teaching foreign languages in Russia. They were asked about the effectiveness of the new methods, such as mobile learning, flipped learning, adaptive learning. 14 teachers answered that they supported the use of the old Russian methods. 6 teachers remained supported the new methods and principles developed in modern neuro-linguistics, such as effective priming or connection with visual forms. Therefore, it is important to find the basis for convergence in the Russian tradition (Moscow psychological school by Vygotsky, Luria, Axutina), proving that there is some theoretical ground in it to perform the transition to the modern methods of teaching. This basis can be found in the results of psychological experiments underlying the theory of speech production, the laws of memory and attention.

\section{Results and discussion}

When analysing traditions of teaching foreign languages, it is necessary to distinguish the following main components: students receive knowledge from the teacher in ready-made forms; they must learn this knowledge without their own analysis and then apply them in exercises. The basis for teaching a foreign language is grammar, which is taught as a set of rules, while the exceptions are memorized by heart. Statements are built as a result of conscious application of the rules. When constructing a statement, the main focus of attention is not the content, but the grammatical rule that should be applied. Vocabulary, selected fairly chaotically, chosen from a specific text, is memorized by the list and checked by translation dictation. The main form of control is the translation from a native language into a foreign language of individual sentences or small texts and so-called topics - prepared speaking on one of the topics covered. The main problem of teaching a foreign language in this method is impossibility to apply knowledge in practice: the vocabulary is limited to the volume learned, there is 
no skill in understanding words from the context, the number of lexical units is limited, since wordformation models are not sufficiently developed, there is no skill in perceiving the content of the text as a whole for a limited period of time, without a literal translation. One of the main problems is the inability to perform a communicative professional task in a limited period of time. The skill of listening, and, consequently, speaking, is poorly developed, there is no natural tempo when pronouncing phrases.

The communicative approach, on the contrary, implies the transfer of the main activity from the language system to the development of communicative skills and, primarily, listening and speaking, the formation of the skill of working with a text as a whole for a certain period of time, developing the ability of understanding of words from the context and using word formation models (Harmer, 2015). The communicative approach is the only possible one in the university standard of instruction for the initial stages of language learning (A1 - A2 in European format). The competence approach, which is the basis of all programs and standards of the university education at present, involves the use of Language for professional purposes, that is the application of communicative skills in practice. The possibility of the solution of professional communicative tasks starts approximately from stage B1 of the all-European standard.

In the new standard of M.V. Lomonosov Moscow State University for students of non-philological specialties studying under the Bachelor's degree program, the following competencies, the formation of which presupposes the use of a foreign language, are distinguished.

Universal competence - 4 . The student is able to carry out non-core (non-profile) communication in oral and written forms in a foreign language (s);

Universal competence -5 . The student is able to perceive the intercultural diversity of society in the socio-historical, ethical and philosophical contexts;

General professional competence - 2. Knowledge of general scientific and professional terminology and conceptual apparatus in its professional field of activity in Russian and foreign languages;

General professional competence - 3. The ability to work with original texts and sources (uncomplicated level of professional texts).

General professional competence - 7. Possession of skills in effective communication in a professional environment, the ability to professionally express thoughts in spoken and written speech.

The basic core of all the competencies mentioned is the use of language as a means of professional communication in practice. This approach to some extent contradicts the traditional methodology, which has been established and is still being applied in the universities. However, unlike the methodology adopted in the tradition, a completely different approach was founded and developed in the Moscow Psychological School in the works by its founders Lev Vygotsky, Alexei Leontyev and their disciples. They substantiated the so-called activity-based approach to learning, which correlates with the formation of competences processes. At the same time, it has not been used in the teaching of foreign languages to the full extent so far. For example, studying the mechanisms of aphasia in their patients, L. Vygotsky, A.N. Leontiev and their disciples (Vygotsky, 1987; Leontiev, 1981; Luria, 1980; Axutina, 2014), came to many interesting conclusions about mechanisms of speech generation in the native language, the attention phenomenon, both voluntary and involuntary, the functions of memory.

The basic model of speech generation in the concept of the Moscow Psychological School, the main conclusions of which were based on studies of aphasia in people who have received brain injuries, includes several levels. The first level is associated with the so-called inner speech activity, dealing with the content of an utterance. Then is the second level, the lexical grammatical one. At this level a selection of lexical units and their grammatical structuring are taking place. It is at this level that the actual utterance in the native or foreign language is being built. Here, the trained schemes of grammatical generation of the utterance and selection of the necessary vocabulary should be realized. The final stage of generating an utterance is its actual production in oral or written speech (Tapiero, 2014).

The main conclusion that can be drawn from their research is related to the presence of holistic (perception in general) and analytical approaches in working with language and text, the need to involve both the left (voluntary attention) and the right hemispheres of the brain (involuntary attention) in the learning process. The mechanisms for memorizing words are related either to their being related to one lexical block, or to 
a certain context, which must be remembered precisely as a context, but not as a collection of individual words. The next very important point to be made is that grammar rules are much more of an explanation than a basis for constructing an utterance. The so-called grammatical figuration of an utterance occurs in the process of applying the developed automated grammatical constructions. Thus, there occurs the only assumption that mechanisms of speech production in the native language are adequate to the ones in a foreign language. In other words, the basis for creating foreign languages teaching methods is not so much a linguistic description of the language, but neurolinguistic mechanisms for generating utterances and forming practical results (competences) that should become the main criterion for evaluation.

According to the activity-based approach, psychological research in terms of learning process is organically connected with the basic idea, according to which the process of development of human consciousness is understood as education in its specifically human forms, that is, in the context of transfer the social and historical experience from one person to another. A.N. Leontiev stressed the need to change the organization of scientific work in the field of educational psychology, the basic requirement of which is that school to become the main place of work for a psychologist, his or her practical clinic (Leontiev, 1981). Within these terms a scientist should not behave both as a guest and an observer in an educational institution, but as an active participant in the pedagogical process, since the study of regularities of human's mental development are regarded as the determining factor in the elaboration of scientifically based methods of teaching and educating. The formation of individual mental processes first and foremost occurs in the course of the development of a particular activity of the personality in connection with the development of his or her psychological structure, direction and motivating peculiarities, but not only in the progressive order of maturation. In this respect, the following basic premises of the theory of activity deserve special attention: questions of the structure of activity, the problem of differentiation between activity and action, which is closely connected with the certain psychological study in the field of the semantic analysis of consciousness and practice of educating in terms of conscious attitude, that is, consciousness of the learning process. Human's personality should be considered not only an object of external influences, but primarily an independent and self-sufficient subject of life and development.

The main condition for the convergence of the national and international standards for teaching a foreign language is the convergence of methods and approaches to teaching, such as the method of submitting material, the role of a teacher, the priority of skills automation for the purpose of their subsequent practical application, the development of a natural rate of speech, the skill of rapid reading for the purpose of understanding text, the transmission of the content of the text as a whole, quick search for information in the text, writing with the use of set phrases and stable designs. All this assumes a fundamentally different approach to the construction of each lesson, to the forms of control and evaluation criteria. The most promising for integration into the traditional lesson model are modern concepts of flipped learning, mobile learning and adaptive learning (Covington, 1998).

The main feature of the flipped learning model is the extension of the phase of exercises. Students do the exercises in class under the supervision of a teacher, preparing the necessary theoretical issues at home. Such model is effective while training speaking and listening skills. The teacher has the ability to correct mistakes accurately (for example, by the "echo" method), and the students have the opportunity to correct them immediately by repeating the correct version after the teacher. The teacher has the opportunity to offer individual assignments depending on the "weak points" of the students. This learning model can be successively used for training grammatical and lexical skills, as well as for integrated skills, for example, listening and speaking, listening and writing. The direct control of a teacher provides the possibility to achieve the necessary results quickly enough. At the same time, it should be noted that the disadvantage of this method is the need for compulsory home preparation, which determines active participation of the students in the class work.

The concept of flipped learning is a complete change in the traditional relationship between a lesson with a teacher and a homework assignment. The most difficult thing within these terms is automating skills, applying them in practice - students should do it independently as homework assignments, the role of a teacher is limited to the source of new information and the controller. In the concept of flipped learning, new information is transferred to students in the form of homework, for example, when they read a text and find new grammatical phenomena, and in class the main role is played by skills automation, deepening of the material studied at home, exercises and application in practice (Flipped learning..., 2015; Straw et al., 2015). The peculiarity of this model is the possibility of clear control by 
the teacher behind the most important phase of teaching foreign languages - for automating grammatically and lexically correct statements, dialogue with the teacher is the primary form of applying a foreign language in practice. Such a model in the teaching of foreign languages seems quite promising (although not without contradictions).

It should be added that there has been written quite a lot about mobile learning. Without the use of digital technologies, it is impossible to create a minimal foreign language environment when learning a foreign language. The importance of the mobile learning model has been repeatedly emphasized in a number of manuals (Attewell et al., 2010; DeGani, Martin, Stead, 2010; Colley, DeGani, Stead, 2010). The advantage of this model, especially when doing homework, is the lack of attachment to a certain location - a classroom, a workplace. The assignments can be fulfilled at any place and time, using, for example, tablets. This creates the illusion of constant presence of a foreign language in the life of students and creates the opportunity to engage in a foreign language on a daily basis, which definitely leads to success. When fulfilling the assignments, you can use time restrictions, which provides the opportunity of using the language at a natural pace. It is especially good to use this model for training grammar, vocabulary, developing listening skills. You may also include Cultural and Regional Studies into the Foreign Language course.

A special role is played by non-promotional materials on the Internet, which actually create samples of professionally oriented situations while using a foreign language (information retrieval, viewing of information channels, business correspondence). The use of didactic materials creates various possibilities for training grammar, vocabulary, and presentation of regional information of various kinds. The use of mobile learning increases the motivation of students and creates the basis for maximum success.

The concept of adaptive learning is related to mobile learning and implies the adaptation of the pace of the course, the material itself and the ways of its submission to specific training objectives and standards set competencies. The interest of students, their abilities and abilities play an important role in the definition of training strategies. The goal is to optimize the learning process, an attempt to overcome the under load or overload of students (Mukherjee, 2013). Therefore, the application of certain student autonomy is a prerequisite for the success of a foreign language course. The adaptive learning model can be regarded as the similar one to flipped learning. The basis of this model is the adaptation of tasks for each student or a group of students according to the level of their abilities. The individual approach to the course construction allows avoiding underloading pupils with good results and overloading the weak ones. As a result, the motivation increases, and the autonomy of students are being developed. This model is particularly effective while making grammar corrections land grammatical material study.

The model of collaborative learning - learning in blogs, chat rooms, and social networks - has become widely spread in recent years (Barkley, Claire, Cross, 2014). This type of learning requires much of the teacher's time being spent on communication and is hardly justifiable. It is believed that such model develops social competencies of students, but according to our estimates, MSU students do not lack such competencies, rather, on the contrary, the propensity to constant net communication prevents them from concentrating on the actual language models' reproduction.

Within these terms the Game-Based-Learning model deserves special attention as implicit learning always involves great interest of students and increases motivation (Bransford, Brown, Cocking, 2000). At the same time, the disadvantage of the model in question as it deals with great, sometimes unjustifiable, efforts from the teacher concerning with creation or adaptation of games. As the most effective games actively used in the process of language learning at Moscow State University one can name debates or discussions concerning a certain subject (topic).

To formulate the competencies declared in the university standard, it is necessary not only to have a certain command of a foreign language at a particular level, to automate the necessary skills and the ability to develop them independently, but also to form non-linguistic skills, such as the ability to search for information, to adapt the received volume of information to the declared format, to present information both orally and in the writing form, the ability to state one's position correctly. Brief presentations, public presentations in the format of a scientific report (for universities), discussions (prepared) and debates (unprepared) are the most appropriate forms for the development of these non-linguistic skills. The sphere of topicalization should always be connected with the future professional activity. 


\section{Conclusion}

The universal competencies of the university graduate and the professional competencies of nonphilological faculty graduates dealing with the need to change not only methods of teaching, but also the methods of control and criteria for evaluating results, which is also the subject for our further investigation. The most promising method of teaching a foreign language is a communicative method, including comments and explanations of the language system and function, with the obligatory use of flipped learning, mobile learning and adaptive learning. The following criteria for evaluating the results can be proposed: the solution of practical professional problems, which primarily assess both linguistic and non-linguistic components such as content, present ability of the material being demonstrated, logical presentation, natural rate of speech and ease of perception for the listener or reader. Language errors are assessed as one of the components of the overall assessment as a whole. You can use these types of tasks for the final or intermediate control: give a presentation (collect the material by yourself and present it in the correct form), participate in the discussion on the given topic (prepare materials, develop your point of view, collect the necessary arguments, correctly and consistently submit your point of view), write an essay on a given subject for those samples that are commonly used in the future profession of the graduate. Such control is as close as possible to practice and will help determine the formation of professional competencies.

Thus, while taking into consideration the neuro-linguistic concept of the Moscow Psychological School as the basis of construction in the foreign language teaching process, what should be the ratio of analytical (the left hemisphere of the brain) and creative (the right hemisphere of the brain) elements, arbitrary and involuntary attention, analysis of language and communication and how should they be correlated on each level of language proficiency.

To set and fulfil the task is undoubtedly complicated, because both the shortcomings of the traditional method as well as those of the communicative one is very well known to professionals. Apparently, in the future, it is necessary to develop a clear methodology for teaching foreign languages, focused on the competencies approach, based on the interaction of communicative and analytical approaches, with the application of modern neuro-linguistics achievements concerning the work of memory, attention and the priming effect, as well as the theory of speech generation created by the Moscow Psychological School.

Therefore, the basic principles of the convergence of new Russian foreign language programs for nonphilological students and the Western standards can be the following:

1. Interaction of communicative and analytical (the analysis of language paradigms) teaching methods, depending on the competencies declared in the educational standards,

2. Integration of all the basic issues of modern neuro-linguistics and psychology - the theory of generating utterances, theory and experiments priming, the use of mechanisms of work of memory and attention,

3. The use of modern approaches such as mobile learning, adaptive learning, flipped learning.

\section{Bibliography}

1. Attewell J., Savill-Smith C., Douch R., Parker G. (2010). Modernising Education and Training: Mobilising Technology for Learning. London: Learning and Skills Network.

2. Axutina T.V. (2014). Nejrolingvisticheskij Analiz Leksiki, Semantiki i Pragmatiki (Neuro-linguistic Analysis of Lexis, Semantics, and Pragmatics). Moskva: Yazyki Slavyanskoj Kultury.

3. Barkley E.F., Claire H.M., Cross K.P. (2014). Collaborative Learning Techniques: A Handbook for College Faculty. (2nd ed.). USA: John Wiley and Sons.

4. Bologna Declaration. (1999). Joint Declaration of the European Ministers of Education. Retrieved from: http://media.ehea.info/file/Ministerial_conferences/02/8/1999_Bologna_Declaration_English_553028.pdf

5. Bransford J.D., Brown A.L., Cocking R.R. (Eds.). (2000). How People Learn: Brain, Mind, Experience, and School. (Expanded ed.). Washington, D.C.: The National Academy Press.

6. Colley J., DeGani A., Stead G. (2010). What in the World are you Doing with your Mobile Phone? World differences in the use of mobiles. Cambridge: Lincoln House.

7. Common European Framework of Reference for Languages: Learning, Teaching, Assessment (CEFR). Companion Volume with New Descriptors. (2017). (Provisional Edition). Strasbourg: Council of Europe. Retrieved from: https://rm.coe.int/common-european-framework-of-referencefor-languages-learning-teaching/168074a4e2 
8. Covington M.V. (1998). The Will to Learn. A Guide for Motivating Young People. London: Cambridge University Press.

9. DeGani A., Martin G., Stead G. (2010). Frances Wade. E-learning Standards for an M-learning World - Informing the Development of E-learning Standards for the Mobile Web. Cambridge: Lincoln House.

10. Flipped learning: Handbook for Schools Implementing Flipped Learning Using Khan Academy. (2015). UK: National Foundation for Educational Research (NFER) and Nesta. Retrieved from: https://www.nesta.org.uk/sites/default/files/flipped_learning_handbook_for_schools.pdf

11. Harmer J. (2015). The Practice of English Language Teaching. (5th ed.). UK: Pearson Education.

12. Leontiev A.N. (1981). Problems of the Development of the Mind. Moscow: Progress-Publishers.

13. Luria A.R. (1980). Higher Cortical Functions in Man. (2nd ed.). USA: Springer US.

14. Mukherjee S. (2013). Adaptive Learning System: A Tool to Personalize Learning. Tata Interactive Systems. Retrieved from http://www.tatainteractive.com/pdf/White-

Paper Adaptive Learning Systems.pdf

15. Obrazovatelnyj standart vishevo obrazovanije samostojatelno ustanovlivajemij moskovskim gosudarstvennim universitetom imeni M.V. Lomonosova (Educational Standard of Higher Education independently established by the Moscow State University on behalf of M.V. Lomonosov). (2015). Moskva: Moskovskij gosudarstvennij universitet imeni M.V. Lomonosova. Retrieved from: https://www.msu.ru/study/docs/380601.pdf (in Russian)

16. Straw S., Quinlan O., Harland J., Walker M. (2015). Flipped Learning - Research Report. London: Nesta. Retrieved from https://www.nfer.ac.uk/publications/NESM01/NESM01.pdf

17. Tapiero I. (2014). Situation Models and Levels of Coherence. Toward a Definition of Comprehension. London: Routlege.

18. Vygotsky L. (1987). Thinking and Speech. In R. Rieber, A. Carton (Eds.), The Collected works of Lev Vygotsky, 1. New York: Plenium. 